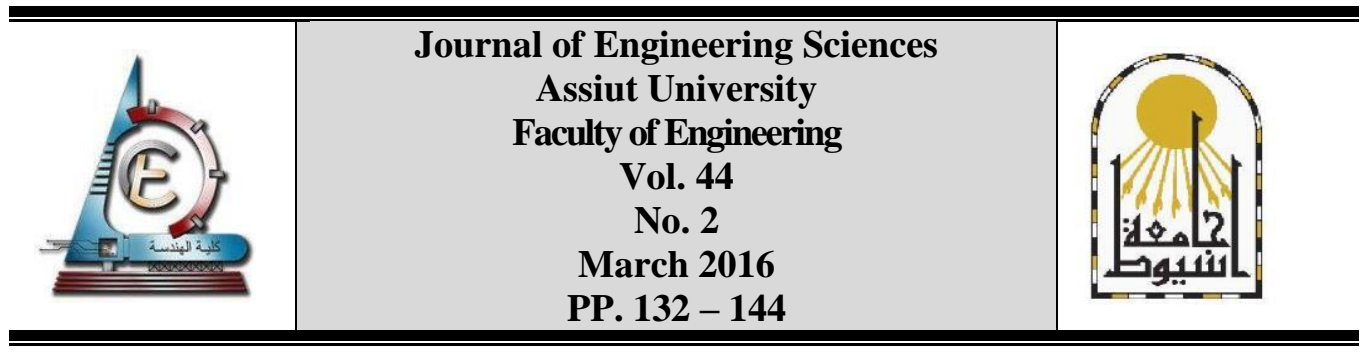

\title{
SHEAR BEHAVIOR OF FIBER REINFORCED CONCRETE BEAMS
}

\author{
Ahmad Saudi Abdul-Zaher ${ }^{1,}$, , Laila Mahmoud Abdul-Hafez ${ }^{2}$, \\ Yasser Rifat Tawfic ${ }^{3}$, Osama Hammed ${ }^{4}$, \\ ${ }^{1}$ Higher Institute of Engineering and Technology in Minia, Egypt \\ 2, 3, ${ }^{4}$ Civil Engineering Department, Minia University, Minia, Egypt
}

Received 25 February 2016; Accepted 14 April 2016

\begin{abstract}
Shear strength of fiber reinforced concrete (FRC) has prime importance in structural design. Concrete members like brackets, corbels and ledger beams may fail in shear. Such failure can be sudden and brittle. The presence of fibers positively affects the behavior of concrete, as it increases the residual shear transfer and reduces the formation and extension of cracks. As many parameters affect it, shear strength of FRC could not be precisely detected. Experimental investigation was carried out to study the shear transfer of un-cracked fibrous concrete. The study investigates the shear strength of FRC beams. The experimental parameters were the type and the percentage of fibers volume fraction and the presence of stirrups in reinforced concrete beams. Test results showed that the presence of fibers resulted in higher values of shear strength, stiffness, ductility and controlled the concrete cracking behavior. Instead of glass fibers, the use of steel fibers improved overall shear behavior of concrete.
\end{abstract}

\section{Introduction}

The brittle and catastrophic shear failure of concrete can be relieved by the addition of fibers.

Previous studies have shown that steel fibers can improve the shear performance of concrete [5], [8], [9], [10], [15]. The use of fibers as shear reinforcement controls the concrete cracking and decreases crack width. However, the results obtained are highly variable [2], [4]. This variability is due to the great diversity of mechanical properties of the FRC, specifically its tensile strength [11], [12], [13], [16]. Swamy et al. [14] conduct experimental tests to identify the behavior of shear strength of FRC. Test results showed that inclusion of fibers increase shear strength and reduce numbers and width of cracks. Tan and Mansur [15] indicated that the inclusion of fibers significantly improves the strength and deformation characteristics of the concrete.

Khaloo and Kim [6] carried out an experimental investigation to assess the effect of concrete strength on the strength and ductility behavior of steel fiber reinforced concrete under direct shear. Test results showed that the enhancement in shear strength, toughness and ductility was more pronounced in high strength concrete than in lower strength concrete.

\footnotetext{
* Corresponding author.

E-mail address:ahmad_sayed@ymail.com
} 
Aziz [1] studied the effect of steel fibers on the shear transfer of RC beams. The results showed that the stirrups strain decrease with increasing fibers volume fraction and reinforcement parameter. Shah and Rangan [18] conducted uni-axial compression test on glass FRC specimens. The results showed that the increase in strength of $6 \%$ to $17 \%$ compressive strength, $18 \%$ to $47 \%$ split tensile strength, $22 \%$ to $63 \%$ flexural strength and $8 \%$ to $25 \%$ modulus of elasticity, respectively. Kim et al. [3] proposed a new type of fiber reinforced polymer (FRP) shear reinforcement as a substitute for steel stirrups. Plate-type FRP shear reinforcement has better constructability and easier fabrication than FRP stirrups. Also, plate shear reinforcement does not reduce the strength by concentrating stress in the bent portion. In an earlier paper, the types of FRP and shape of reinforcement did not significantly affect the shear strength. Based on previous research about high ductile fiber reinforced concrete (HDC) mechanical property [7], [17], it is proposed that the failure mode, deformation behavior, and shear capacity of steel-concrete composite beams would be improved by using HDC. The test results of six high ductile fiber reinforced concrete (HDC) beams were studied to investigate the influence of shear-span ratio and HDC mechanical property on the improvement of the shear failure mode and shear capacity of short beams.

The objective of this research was to investigate the effect of addition of steel or glass fiber on the shear behavior of RC beams with or without stirrups in the critical shear zone.

\section{Layout of experimental work}

The experimental program is to investigate the shear behavior of FRC beams. This includes 12 rectangular RC beams having $12 \mathrm{~cm}$ width, $30 \mathrm{~cm}$ depth and $130 \mathrm{~cm}$ length of span as shown in figures (1) and (2). The RC beams were tested to evaluate the effect of steel or glass fibers on the shear behavior of beams. The variables were the type of fibers (glass and steel), the volume fraction of fibers $(0 \%, 0.2 \%, 0.4 \%$ and $0.6 \%)$ and the presence of stirrups in the shear zone. All RC beams have $325 \mathrm{~kg} / \mathrm{cm}^{2}$ compressive strength and table (1) summaries the details of the tested RC beams. To perform the tests, the beams were simply supported and subjected to three loading points ( 2 support points and 1 load point). These beams were tested up to failure under gradual increasing load in a Universal Test Machine. All beams were tested after 28 days. A dial gauge was fixed at the bottom of beams to measure the deflection under the load application, also an extensometer and strain indicator were used to measure strain of concrete and strain of reinforcement, respectively. All beams were casted and tested at the concrete and strength of material laboratory of Civil Engineering Department, Faculty of Engineering, El-Minia University.

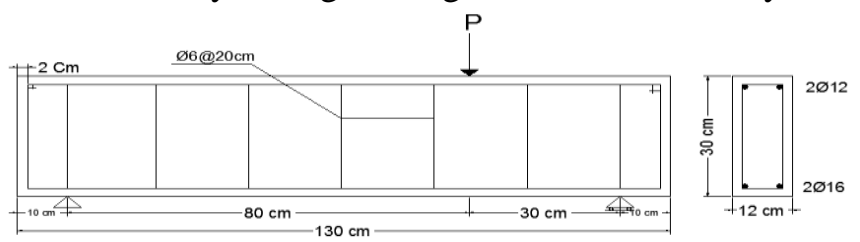

Fig. 1. Concrete dimensions and details of the internal reinforcement for beams $\left(A_{1}\right.$ to $\left.A_{5}\right)$

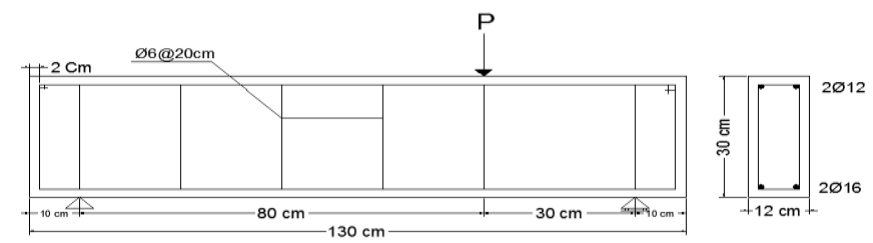

Fig. 2. Concrete dimensions and details of the internal reinforcement for beams $\left(B_{1}\right.$ to $\left.B_{7}\right)$ 
JES, Assiut University, Faculty of Engineering, Vol. 44, No. 2, March 2016, pp. 132 - 144

\section{Table 1.}

Data of the tested beams

\begin{tabular}{|c|c|c|c|c|c|c|}
\hline Group & $\begin{array}{l}\text { No. of } \\
\text { Beams }\end{array}$ & $\begin{array}{c}\text { Compressive } \\
\text { strength } \\
\text { F }_{\mathrm{cu}}\left(\mathrm{kg} / \mathrm{cm}^{2}\right) \\
\end{array}$ & $\begin{array}{c}\text { Percentage of } \\
\text { fiber } V_{f} \%\end{array}$ & $\begin{array}{l}\text { Length } \\
\text { of fiber } \\
(\mathrm{mm})\end{array}$ & $\begin{array}{c}\text { Aspect } \\
\text { ratio } \\
\left(\mathbf{L}_{\mathrm{f}} / \mathbf{d}_{\mathrm{f}}\right) \\
\end{array}$ & Type of fiber \\
\hline \multicolumn{7}{|c|}{ First group with presence of stirrups in the critical shear zone } \\
\hline \multirow{5}{*}{ I } & A 1 & 343.70 & 0.00 & $\begin{array}{ll}---- \\
\end{array}$ & 0 & No Fiber \\
\hline & A 2 & 348.98 & 0.20 & \multirow{2}{*}{50} & \multirow{2}{*}{50} & \multirow{2}{*}{$\begin{array}{c}\text { Steel fiber } \\
\text { (Corrugated) }\end{array}$} \\
\hline & A 3 & 358.46 & 0.60 & & & \\
\hline & A 4 & 347.20 & 0.20 & \multirow{2}{*}{12} & \multirow{2}{*}{120} & \multirow{2}{*}{ Glass fiber } \\
\hline & A 5 & 352.92 & 0.60 & & & \\
\hline \multicolumn{7}{|c|}{ Second group without stirrups in the critical shear zone } \\
\hline \multirow{7}{*}{ II } & B 1 & 343.70 & 0.00 & ---- & 0 & No Fiber \\
\hline & B 2 & 348.98 & 0.20 & \multirow{3}{*}{50} & \multirow{3}{*}{50} & \multirow{3}{*}{$\begin{array}{c}\text { Steel fiber } \\
\text { (Corrugated) }\end{array}$} \\
\hline & B 3 & 353.16 & 0.40 & & & \\
\hline & B 4 & 358.46 & 0.60 & & & \\
\hline & B 5 & 347.20 & 0.20 & \multirow{3}{*}{12} & \multirow{3}{*}{120} & \multirow{3}{*}{ Glass fiber } \\
\hline & B 6 & 350.58 & 0.40 & & & \\
\hline & B 7 & 352.92 & 0.60 & & & \\
\hline
\end{tabular}

\section{Material properties}

Test specimens were cast using coarse aggregate, fine aggregate, cement, water, super plasticizer and fibers. The physical properties of the material used in the mix are as follows:

1- Coarse aggregate: Gravel supplied from local quarries, have maximum nominal size of $20 \mathrm{~mm}$ was used to cast all specimens. The specific gravity, volume weight, fineness modulus were $2.5,1.54 \mathrm{t} / \mathrm{m}^{3}$ and 6.37 , respectively.

2- Fine aggregate: The fine aggregate was natural desert sand, clean and free from silt and clay. The specific gravity, volume weight, fineness modulus were $2.5,1.7 \mathrm{t} / \mathrm{m}^{3}$ and 3.4 , respectively.

3- Cement: Ordinary Portland cement was used. The specific gravity and fineness specific surface area were 3.15 and $3250 \mathrm{~cm}^{2} / \mathrm{g}$, respectively.

4- Water: Drinking water was used for mixing and curing of concrete.

5- Super plasticizer: Super plasticizer improves the workability and compressive strength of concrete.

6- Fibers: Steel and glass fibers were used in test specimens, the properties of steel and glass fibers are shown in table (2).

Table 2.

Properties of fiber

\begin{tabular}{|c|c|c|c|c|c|c|}
\hline Materials & Type & $\begin{array}{c}\text { Density } \\
\left(\mathrm{t} / \mathrm{m}^{3}\right)\end{array}$ & $\begin{array}{c}\text { Young's } \\
\text { modulus } \\
\left(\mathrm{t} / \mathrm{cm}^{2}\right)\end{array}$ & $\begin{array}{c}\text { Tensile } \\
\text { strength } \\
\left(\mathrm{kg} / \mathrm{cm}^{2}\right)\end{array}$ & $\begin{array}{c}\text { Length } \\
(\mathbf{m m})\end{array}$ & $\begin{array}{l}\text { Thickness } \\
\text { (mm) }\end{array}$ \\
\hline \multirow{2}{*}{ Steel } & \multirow{2}{*}{ Corrugated } & \multirow{2}{*}{7.85} & \multirow{2}{*}{2100} & \multirow{2}{*}{8500} & 50 & \multirow{2}{*}{1} \\
\hline & & & & & 25 & \\
\hline Glass & Straight & 2.6 & 750 & 2500 & 12 & 0.1 \\
\hline
\end{tabular}

\section{Mixture proportioning}

Concrete mix was designed to give compressive strength $\left(325 \mathrm{~kg} / \mathrm{cm}^{2}\right)$ after 28 days. Table (3) lists weight of the materials used in the mix. 
Ahmad Saudi Abdul-Zaher et al., Shear behavior of fiber reinforced concrete beams

Table 3.

Weights of the materials used in the mix

\begin{tabular}{|c|c|c|c|c|c|c|}
\hline \multicolumn{5}{|c|}{ Components materials } & \multirow{2}{*}{ W/C } & \multirow{2}{*}{ SP/C } \\
\cline { 1 - 5 } $\mathrm{C} \mathrm{kg} / \mathrm{m}^{3}$ & $\mathrm{G} \mathrm{kg} / \mathrm{m}^{3}$ & $\mathrm{~S} \mathrm{~kg} / \mathrm{m}^{3}$ & $\mathrm{~W}$ liter $/ \mathrm{m}^{3}$ & $\mathrm{SP}$ liter $/ \mathrm{m}^{3}$ & & \\
\hline 350 & 1188 & 590 & 165 & 3.5 & 0.47 & 0.01 \\
\hline
\end{tabular}

C: Cement, G: Gravel, S: Sand, W: Water, SP: Super plasticizer.

\section{Results and Discussion}

Test results of cracking and ultimate load, concrete strain, steel strain and deflection for $\mathrm{RC}$ beams were recorded and listed in table (4).

\subsection{Cracking patterns and modes of failure}

Figure (3) shows the patterns of cracks and modes of failure for the RC tested beams. In general, all RC tested beams failed due to shear. On loading the control beam $\mathrm{A}_{1}$ (reinforced with stirrups in the shear zone and has no fibers); flexural crack initiated under point of load application. As the applied load increases, more flexural cracks were formed and propagated upward and were followed by the initiation of an inclined crack. The inclined crack was extended upward and downward and more diagonal tension cracks were formed in the region of maximum shear zone leading to the failure of the RC beams. The presence of low fiber volume fraction (up to $0.2 \%$ ) showed no clear difference in the patterns of cracks and modes of failure when compared to the control beam. As the percentage of volume fraction of steel or glass fibers increases (up to $0.6 \%$ ) for beams $\mathrm{A}_{3}$ and $\mathrm{A}_{5}$, higher values of first shear cracking loads were detected and the cracks were spaced more closely. It is found that with the increase of the fiber volume fraction results in higher values of the concrete tensile strength and modulus of elasticity, and consequently the stiffness of the RC beams increased. Alternate to the control beam (first group) $A_{1}$, the failure of the control beam $B_{1}$ (without reinforced stirrups in the shear zone and has no fibers, second group) was sudden and brittle. The main reason of the sudden and brittle type of failure of beam $\mathrm{B}_{1}$ was due to the removal of the shear reinforcement from the critical shear zone. The general trend of failure and patterns of cracks for beams $\left(B_{2}, B_{5}\right)$ has low percentage of fiber up to $0.2 \%$ were similar to that of the control beam $B_{1}$, however slightly higher number of cracks were observed. Increasing the value of percentage of steel or glass fibers (up to $0.6 \%$ ) resulted in higher value of first cracking load as well as higher numbers of cracks. Compared to the control beam $\mathrm{B}_{1}$, the presence of fibers has obviously positively affected the ductility of beams $\left(\mathrm{B}_{3}, \mathrm{~B}_{4}, \mathrm{~B}_{6}\right.$ and $\left.\mathrm{B}_{7}\right)$. The comparisons between the beams in group I and group II showed that the presence of stirrups in the shear zone minimizes the occurrence of the sudden and brittle type of the shear failure and improves the general behavior of the RC tested beams.

\subsection{Shear cracking load}

The first shear cracking load (FSCL) is the load at which the first diagonal crack was initiated in the critical shear zone. Figure (4) and table (4) show the first shear cracking load for all $\mathrm{RC}$ tested beams. Compared to the control beam $\mathrm{A}_{1}$, beams $\left(\mathrm{A}_{2}, \mathrm{~A}_{3}, \mathrm{~A}_{4}\right.$ and $\mathrm{A}_{5}$ ) (have stirrups in the critical shear zone) showed higher values of FSCL with the enhancement ranged from $5.88 \%$ to $23.53 \%$. The presence of $0.2 \%$ steel fibers for beam $\mathrm{A}_{2}$ and the presence of $0.6 \%$ steel fiber for beam $\mathrm{A}_{3}$ resulted in $17.65 \%$ and $23.53 \%$ increase for the 
JES, Assiut University, Faculty of Engineering, Vol. 44, No. 2, March 2016, pp. 132 - 144

values of the FSCL, respectively. However, the presence of $0.2 \%$ and $0.6 \%$ of glass fiber for beams $\mathrm{A}_{4}$ and $\mathrm{A}_{5}$ led to an enhancement $5.88 \%$ and $11.76 \%$, respectively. The use of steel fibers, showed higher values of the shear cracking loads than the use of glass fibers, because the steel fibers have higher values of modulus of elasticity and tensile strength.
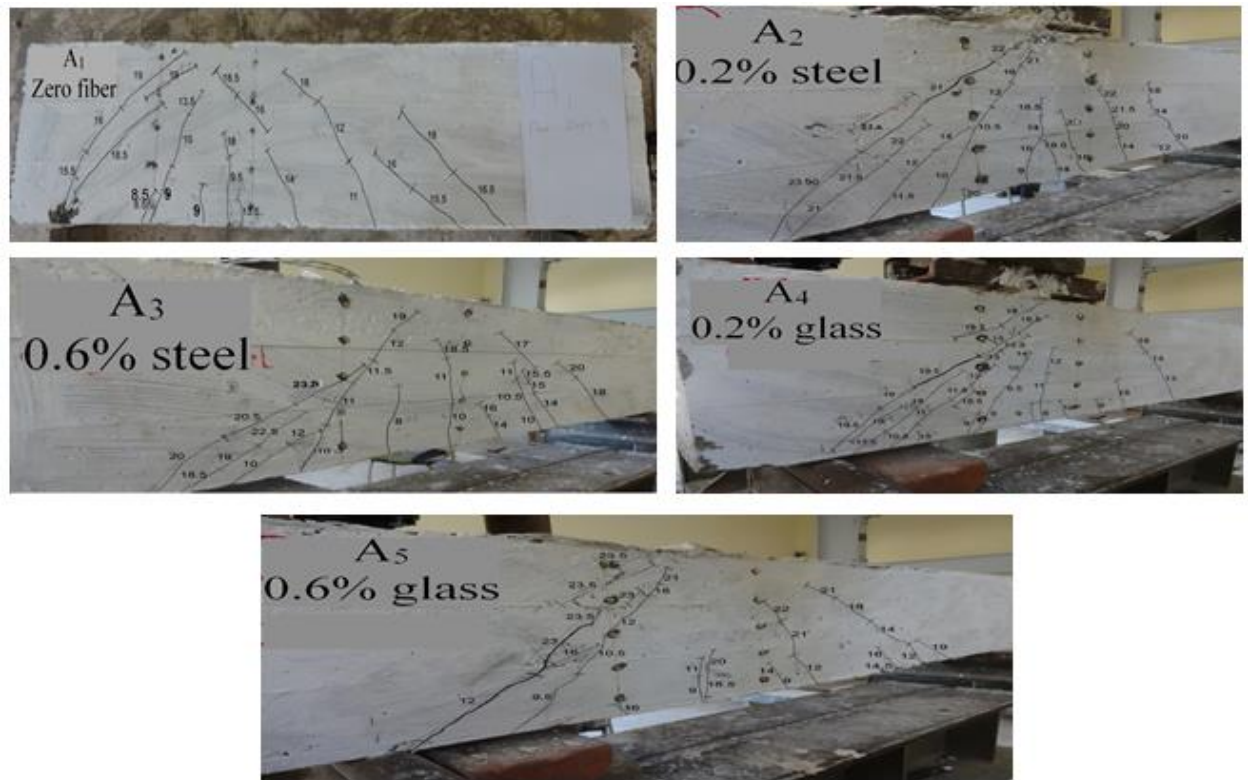

a) First group beams
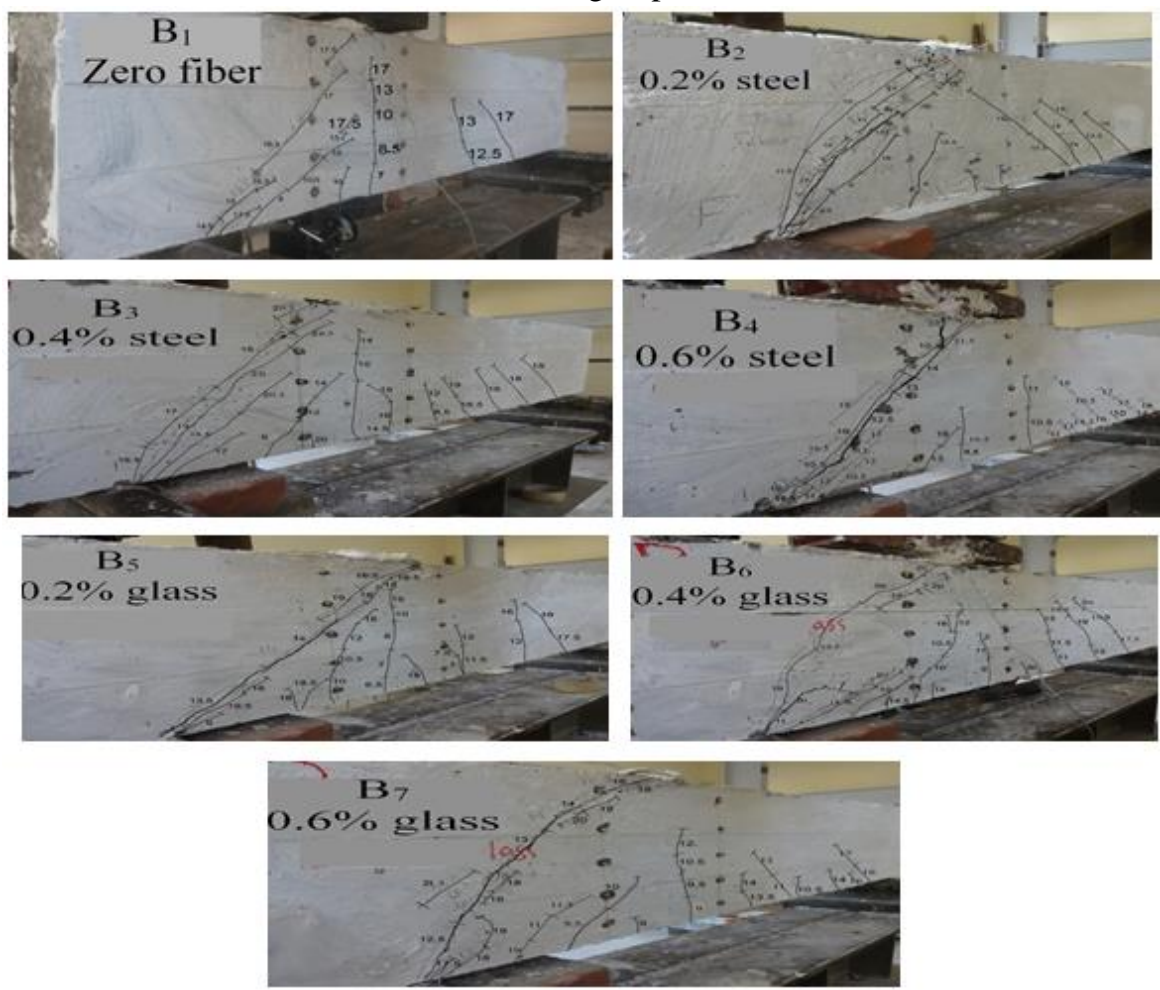

b) Second group beams

Fig. 3. Patterns of cracks and shapes of failure for beams 
The presence of steel or glass fibers for the beams in the second group (have no stirrups in the critical shear zone) showed $6.25 \%$ to $31.25 \%$ increase for the value of the FSCL when compared to control beam $\mathrm{B}_{1}$. The presence of $0.2 \%, 0.4 \%$ and $0.6 \%$ of steel fibers for beams $\mathrm{B}_{2}, \mathrm{~B}_{3}$ and $\mathrm{B}_{4}$ resulted in $12.5 \%, 25 \%$ and $31.25 \%$ increase for the values of the FSCL, respectively. However, the presence of $0.2 \%, 0.4 \%$ and $0.6 \%$ of glass fiber for beams $\mathrm{B}_{5}, \mathrm{~B}_{6}$ and $\mathrm{B}_{7}$ led to $6.25 \%, 12.50 \%$ and $18.75 \%$ increase for the values of the FSCL, respectively.

Compared to the control beam, the presence of fiber showed higher enhancement for the values of the FSCL particularity for beams with no stirrups in the critical shear zone when compared to those having stirrups in the critical shear zone. This may be attributed to the high shear capacity of beams provided with stirrups.

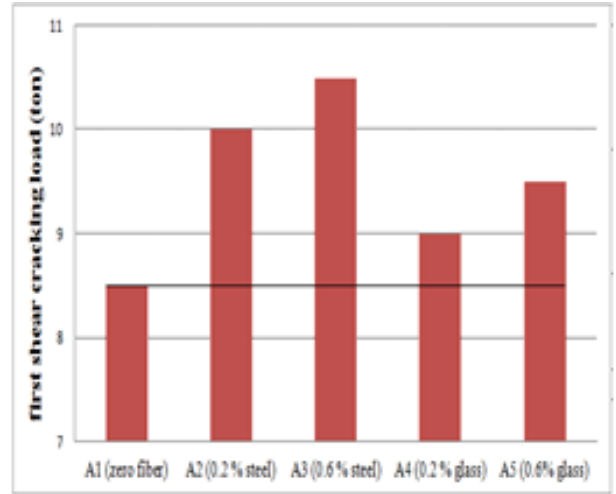

a) First group beams

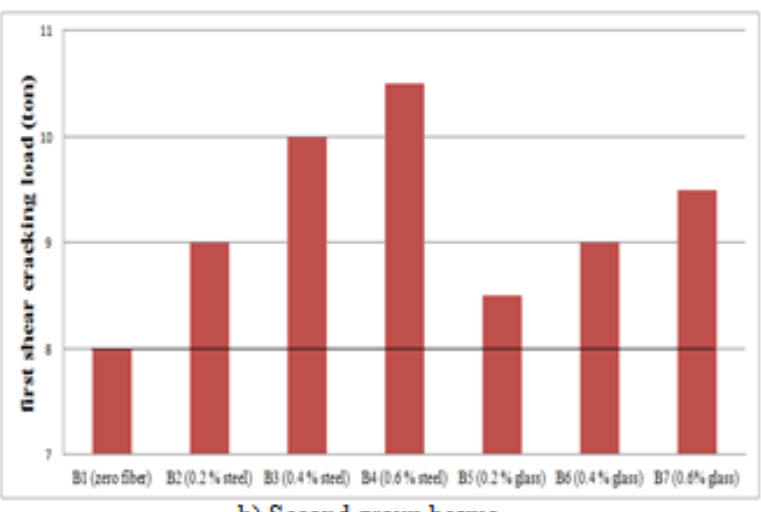

b) Second group beams

Fig. 4. First shear cracking load for beams

\subsection{Ultimate load}

Figure (5) and table (4) show that the presence of fibers led to enhancement for the value of the ultimate loads particularity for beams of highest fiber volume fraction. Beams $\left(\mathrm{A}_{2}, \mathrm{~A}_{3}, \mathrm{~A}_{4}\right.$ and $\left.\mathrm{A}_{5}\right)$ (have stirrups in the critical shear zone) showed about $4.21 \%$ to 25.79 $\%$ increase for the value of the ultimate load when compared to the control beam $A_{1}$. The presence of $0.2 \%$ and $0.6 \%$ steel fibers for beams $A_{2}$ and $A_{3}$ resulted in $18.95 \%$ and 25.79 $\%$ increase for the values of the ultimate load, respectively. However, the presence of $0.2 \%$ and $0.6 \%$ glass fibers for beams $\mathrm{A}_{4}$ and $\mathrm{A}_{5}$ led to the increase of the percentage of the value of the ultimate load to $4.21 \%$ and $18.42 \%$, respectively. The values of the ultimate load by using steel is higher than the values of the ultimate load by using glass fibers, because the steel fibers have higher values of modulus of elasticity and tensile strength.

Beams in the second group (have fiber and have no stirrups in the critical shear zone) showed higher values of the ultimate load with percentage ranged from $2.86 \%$ to $28.57 \%$ when compared to the control beam $\mathrm{B}_{1}$. The presence of $0.2 \%, 0.4 \%$ and $0.6 \%$ steel fibers for beams $\mathrm{B}_{2}, \mathrm{~B}_{3}$ and $\mathrm{B}_{4}$ resulted in $11.43 \%, 17.14 \%$ and $28.57 \%$ increase for the values of the ultimate loads, respectively. However, the presence of $0.2 \%, 0.4 \%$ and $0.6 \%$ of glass fiber for beams $\mathrm{B}_{5}, \mathrm{~B}_{6}$ and $\mathrm{B}_{7}$ led to $2.86 \%, 14.29 \%$ and $22.86 \%$ increase for the value of the ultimate load, respectively.

The efficiency of using fibers to increase the shear capacity was found to be high for beams having no stirrups in the critical shear zone. However, using of stirrups and fibers resulted in higher values of ultimate loads. 


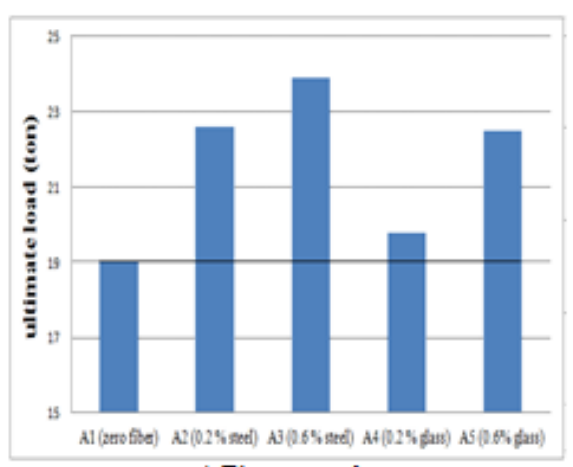

a) First group beams

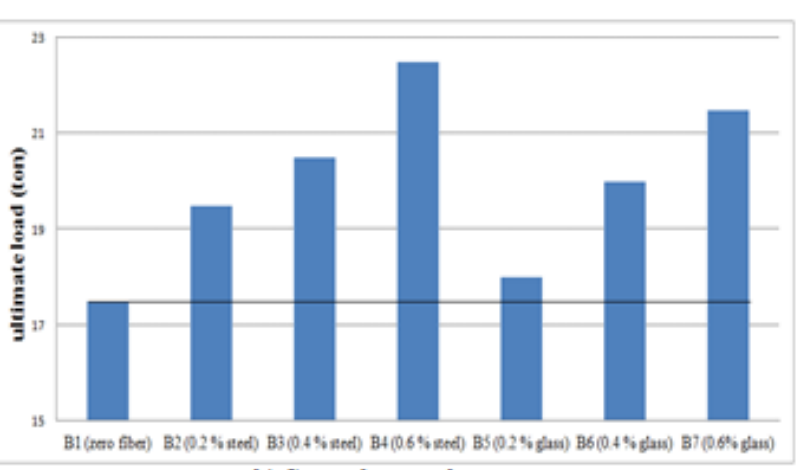

b) Second group beams

Fig. 5. Ultimate load for beams

Table 4.

Experimental Test Results of Beams

\begin{tabular}{|c|c|c|c|c|c|c|c|c|c|c|c|}
\hline \multirow{2}{*}{ 幽 } & $=0$ & 0 & Type & $\mathbf{P}_{\text {cr }}$ & $\mathbf{P}_{\text {ult. }}$ & \multirow{2}{*}{ تص } & $\boldsymbol{\delta}_{\mathrm{u}}$ & \multirow{2}{*}{ لَ } & \multirow{2}{*}{ 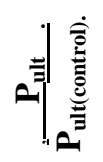 } & \multirow{2}{*}{ 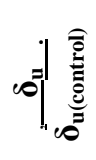 } & \multirow{2}{*}{ 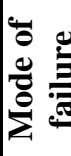 } \\
\hline & $\mathbf{Z}$ & $>$ & fiber & ton & ton & & $\mathrm{mm}$ & & & & \\
\hline \multicolumn{11}{|c|}{ first group with stirrups in shear zone } & \multirow{6}{*}{ 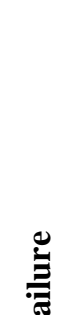 } \\
\hline \multirow{5}{*}{ I } & $\mathrm{A}_{1}$ & 0.0 & No fiber & 8.5 & 19 & 0.45 & 2.4 & 1.00 & 1.00 & 1.00 & \\
\hline & $\mathrm{A}_{2}$ & 0.2 & \multirow{2}{*}{ Steel } & 10 & 22.6 & 0.44 & 2.85 & 1.18 & 1.19 & 1.19 & \\
\hline & $\mathrm{A}_{3}$ & 0.6 & & 10.5 & 23.9 & 0.44 & 3.26 & 1.24 & 1.26 & 1.36 & \\
\hline & $\mathrm{A}_{4}$ & 0.2 & \multirow{2}{*}{ Glass } & 9 & 19.8 & 0.45 & 2.75 & 1.06 & 1.04 & 1.15 & \\
\hline & $\mathrm{A}_{5}$ & 0.6 & & 9.5 & 22.5 & 0.42 & 3.10 & 1.12 & 1.18 & 1.29 & \\
\hline \multicolumn{11}{|c|}{ Second group without stirrups in shear zone } & G] \\
\hline \multirow{7}{*}{ II } & $\mathrm{B}_{1}$ & 0.0 & No fiber & 8 & 17.5 & 0.46 & 2.2 & 1.00 & 1.00 & 1.00 & \\
\hline & $\mathrm{B}_{2}$ & 0.2 & \multirow{3}{*}{ Steel } & 9 & 19.5 & 0.46 & 2.6 & 1.13 & 1.11 & 1.18 & \\
\hline & $\mathrm{B}_{3}$ & 0.4 & & 10 & 20.5 & 0.49 & 2.71 & 1.25 & 1.17 & 1.23 & \\
\hline & $\mathrm{B}_{4}$ & 0.6 & & 10.5 & 22.5 & 0.47 & 2.88 & 1.31 & 1.29 & 1.31 & \\
\hline & $\mathrm{B}_{5}$ & 0.2 & \multirow{3}{*}{ Glass } & 8.5 & 18 & 0.47 & 2.44 & 1.06 & 1.03 & 1.11 & \\
\hline & $\mathrm{B}_{6}$ & 0.4 & & 9 & 20 & 0.45 & 2.63 & 1.13 & 1.14 & 1.20 & \\
\hline & $\mathrm{B}_{7}$ & 0.6 & & 9.5 & 21.5 & 0.44 & 2.73 & 1.19 & 1.23 & 1.24 & \\
\hline
\end{tabular}

$\mathbf{V}_{\mathbf{f}}$ : fiber volume content, $\mathbf{F}_{\mathrm{cu}}$ : average compressive strength of beams, $\mathbf{P}_{\mathrm{cr}}$ : first crack load, $\mathbf{P}_{\text {ult.: }}$ ultimate load, $\boldsymbol{\delta}$ u: max. Deflection, $\mathbf{A}_{\mathbf{1}}$ : control beam at first group, $\mathbf{B}_{\mathbf{1}}$ : control beam at second group.

\subsection{Deflection}

The load-deflection relationship for all RC tested beams is presented in figure (6) and the maximum values of deflection are tabulated in table (4). The curves show that the beams exhibit three stages: the first stage which is the un-cracking stage. This stage starts from zero loading till the first flexural cracking load. The behavior in this stage is characterized by the un-cracked behavior where the maximum tensile stress is less than the concrete flexural tensile strength. The second stage which is the post- cracking stage begins with the first flexural cracking. After cracking, lower values of stiffness were 
detected. The third stage, which is the post-serviceability stage, beams behaved with significantly reduced stiffness till the failure compared with the previous stage.

For beams having $0.4 \%$ and $0.6 \%$ fiber volume fraction at a certain load, the values of the deflection was found to be reduced. This may be attributed to the increase of the stiffness, the value of the modulus of elasticity and the tensile strength of the concrete due to the presence of fibers. However, the presence of low fiber volume fraction $(0.2 \%)$ showed no clear difference in the deflection curve when compared to the control beam. At failure load; the presence of fibers resulted in increase the values of the maximum deflection with percentage ranged from $10.76 \%$ to $29.17 \%$. Because the presence of fibers resulted in higher values of ultimate load as well as higher values of the maximum deflection.
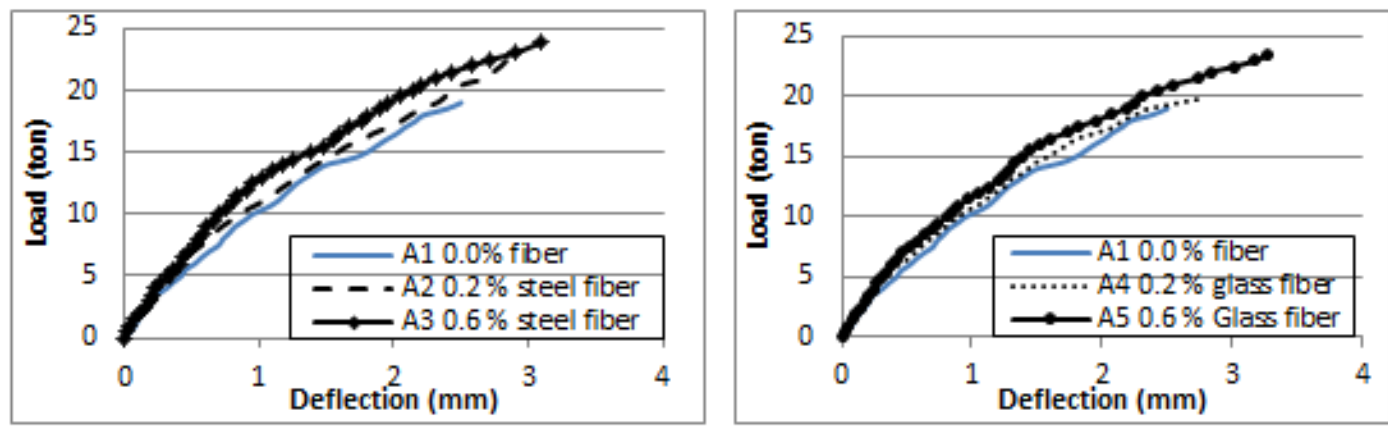

a) First group beams
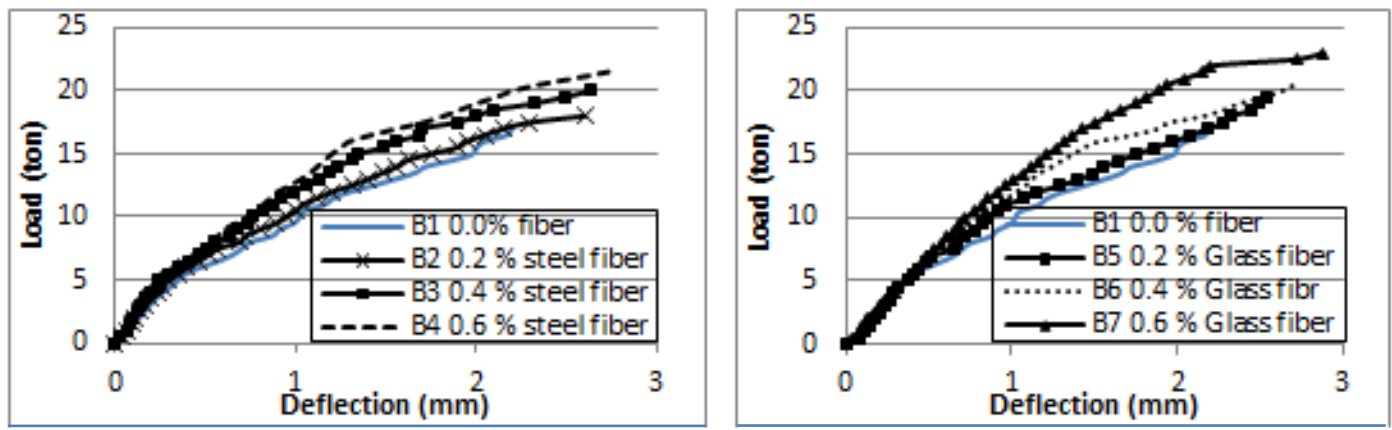

b) Second group beams

Fig. 6. Load-deflection curves for tested beams

\subsection{Ductility}

Figure (7) shows the values of the ductility for all tested beams. The ductility can either be represented in terms of the ratio of maximum deflection to the yield deflection; both measured at under point load, or in terms of the stain energy consumed by the beams during the test measured as the area under the load deflection curve. Since the flexure mode of failure has been secured for all specimens to allow for shear mode of failure, it is found more appropriate to use the second measure of ductility. Beams $\left(\mathrm{A}_{2}, \mathrm{~A}_{3}, \mathrm{~A}_{4}\right.$ and $\left.\mathrm{A}_{5}\right)$ (have stirrups in the critical shear zone) showed about $25.96 \%$ to $76.86 \%$ percentage of increase for the values of the ductility when compared to the control beam $A_{1}$. The presence of $0.2 \%$ and $0.6 \%$ steel fibers for beams $\mathrm{A}_{2}$ and $\mathrm{A}_{3}$ resulted in $36.32 \%$ and $76.86 \%$ increase for the values of the ductility, respectively. However, the presence of 
JES, Assiut University, Faculty of Engineering, Vol. 44, No. 2, March 2016, pp. 132 - 144

$0.2 \%$ and $0.6 \%$ glass fibers for beams $\mathrm{A}_{4}$ and $\mathrm{A}_{5}$ led to the increase of the value of the ductility by $25.96 \%$ and $57.46 \%$, respectively.

Beams in the second group (have fiber and have no stirrups in the critical shear zone) showed higher values of the ductility with percentage ranged from $26.52 \%$ to $78.42 \%$ when compared to the control beam $\mathrm{B}_{1}$. The presence of $0.2 \%, 0.4 \%$ and $0.6 \%$ steel fibers for beams $\mathrm{B}_{2}, \mathrm{~B}_{3}$ and $\mathrm{B}_{4}$ resulted in $39.44 \%, 59.11 \%$ and $78.42 \%$ increase for the values of the ductility respectively. However, the presence of $0.2 \%, 0.4 \%$ and $0.6 \%$ of glass fiber for beams $\mathrm{B}_{5}, \mathrm{~B}_{6}$ and $\mathrm{B}_{7}$ led to $26.52 \%, 54.75 \%$ and $77.32 \%$ increase for the value of the ductility respectively. The presence of steel fibers resulted in higher value of ductility than the use of glass fibers, because the steel fibers have higher values of tensile strength and modulus of elasticity.

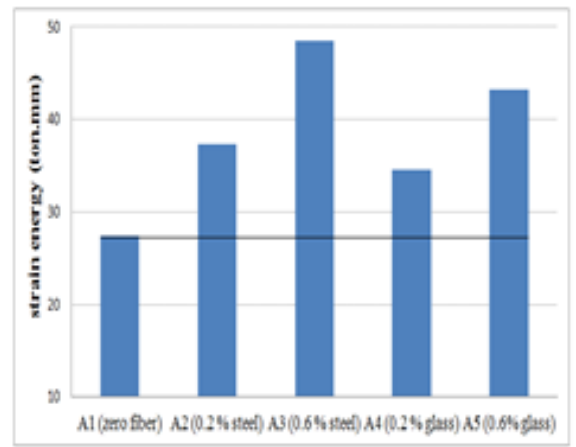

a) First group beams

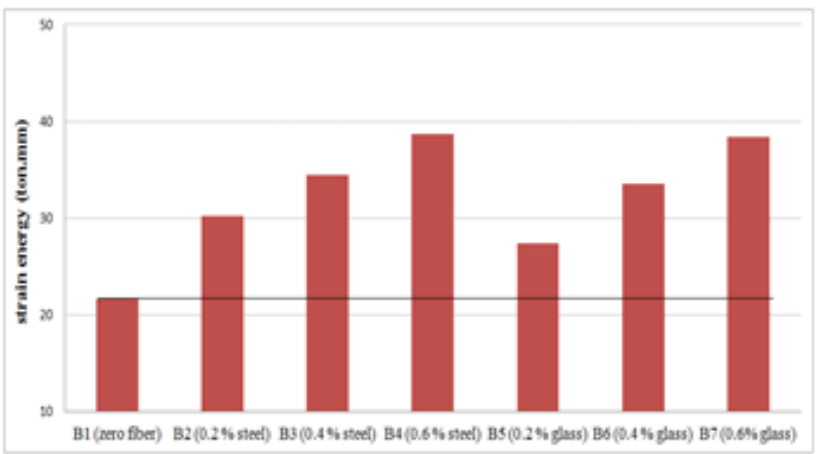

b) Second group beams

Fig. 7. Ductility measured for all beams

\subsection{Stirrups strain}

Electrical strain gauges were used to measure the strains induced at the center of stirrups. Figure (8) shows the relation between the applied load and the corresponding strain in the stirrups for the tested beams in group (1). The presence of steel or glass fibers led to decrease the value of the stirrup strain at a certain load. It also increases the load carrying capacity of beams and consequently increases the values of the maximum stirrups strain. The values of the maximum stirrups strain approximately equal to the value of the yield strain of stirrups.
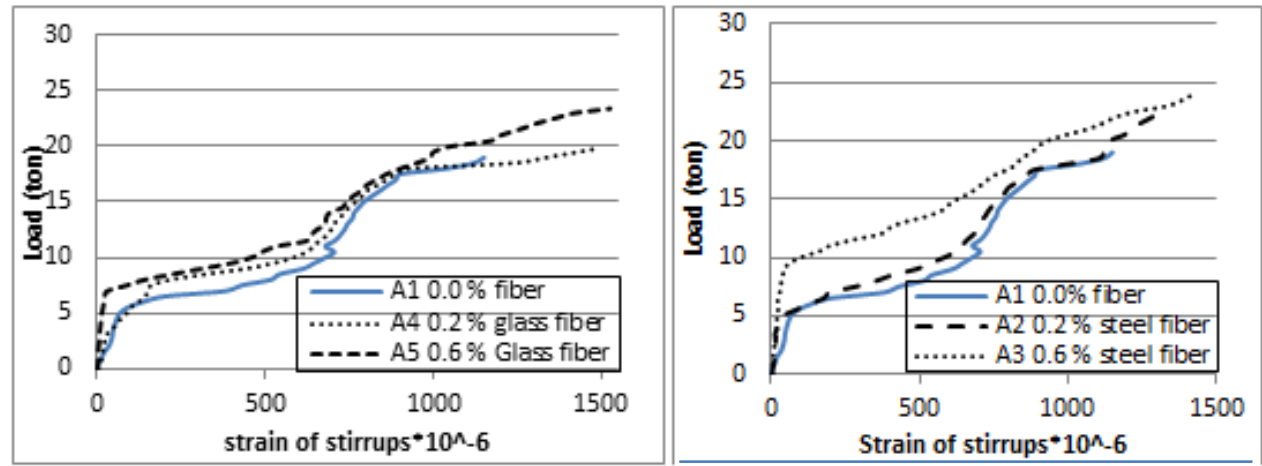

Fig. 8. Load-stirrups strain curves for beams

\subsection{Strain in main steel}

Figure (9) shows the relation between the applied load and the strain of the tensile reinforcement for the tested beams. Electrical strain gauges were used for measuring the strains in main steel bars under the load. Unfortunately, the strain gauge for beam $\mathrm{A}_{3}$ was 
damaged. Before cracking, small values of the steel strain have been recorded due to the fact that the concrete carries the tensile stress. After cracking, the value of the steel strain started to increase until the failure. The presence of steel or glass fibers decreases the value of steel strain at a certain load. However, increasing the load carrying capacity of beams consequently increases the values of the maximum steel strain. The values of the maximum steel strain for all beams are found to be close to the value of strain at yield.
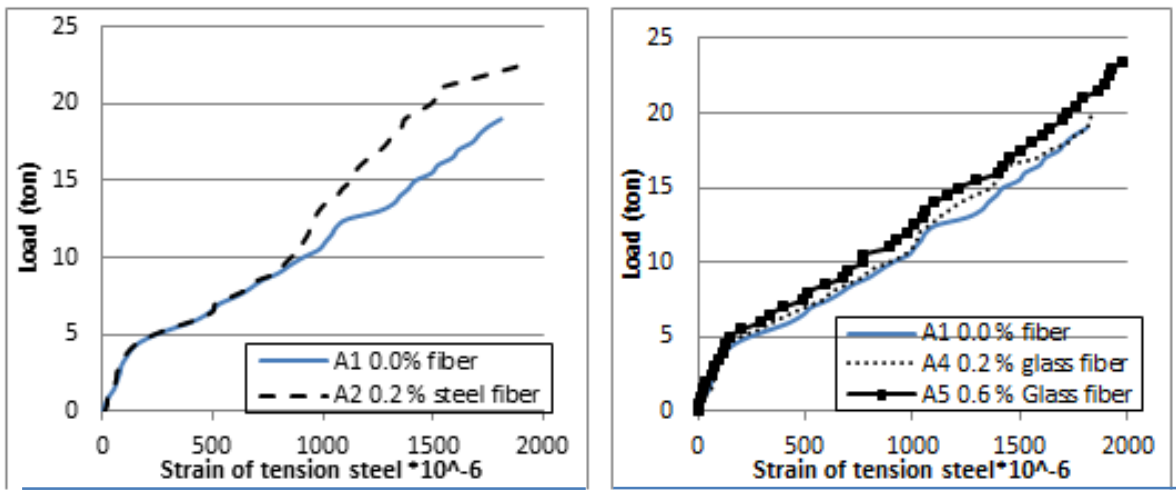

a) First group beams
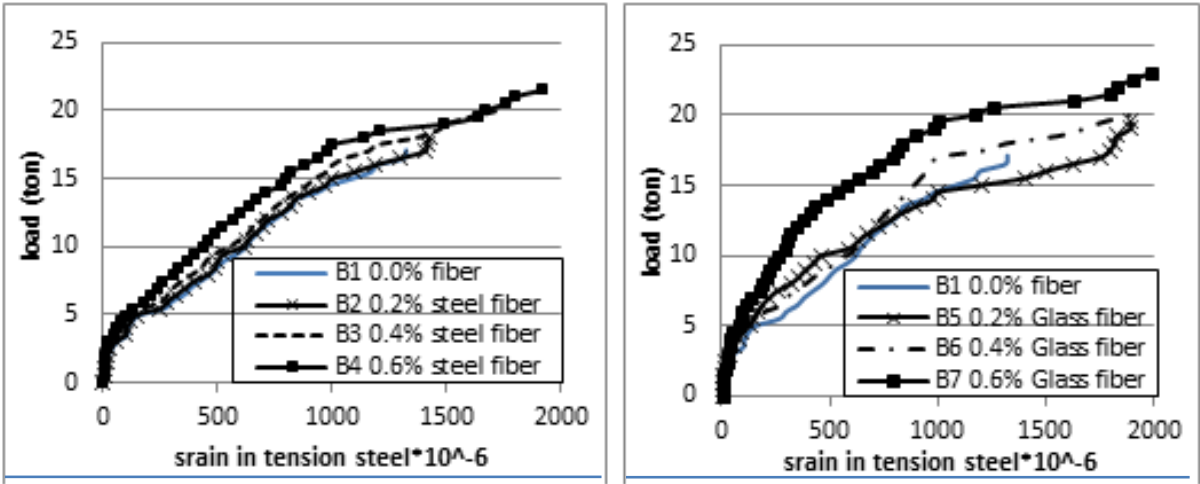

b) Second group beams

Fig. 9. Load-tension steel strain curves for beams

\subsection{Concrete strain}

Figure (10) shows the loads - concrete compressive strain relationship. The values of concrete strain were measured by using the extensometer. The general behavior is similar to the overall behavior of the load-deflection curves. At a certain load, the increase of the percentage of fibers led to decrease the concrete strain. Due to the presence of fiber, concrete absorbs more energy, and as a result the values of both modulus of elasticity and tensile strength of concrete increases. At failure load, the value of the maximum concrete strain increases with increasing the percentage of steel or glass fiber. The values of the maximum strain of concrete for all beams were less than 0.002 . 

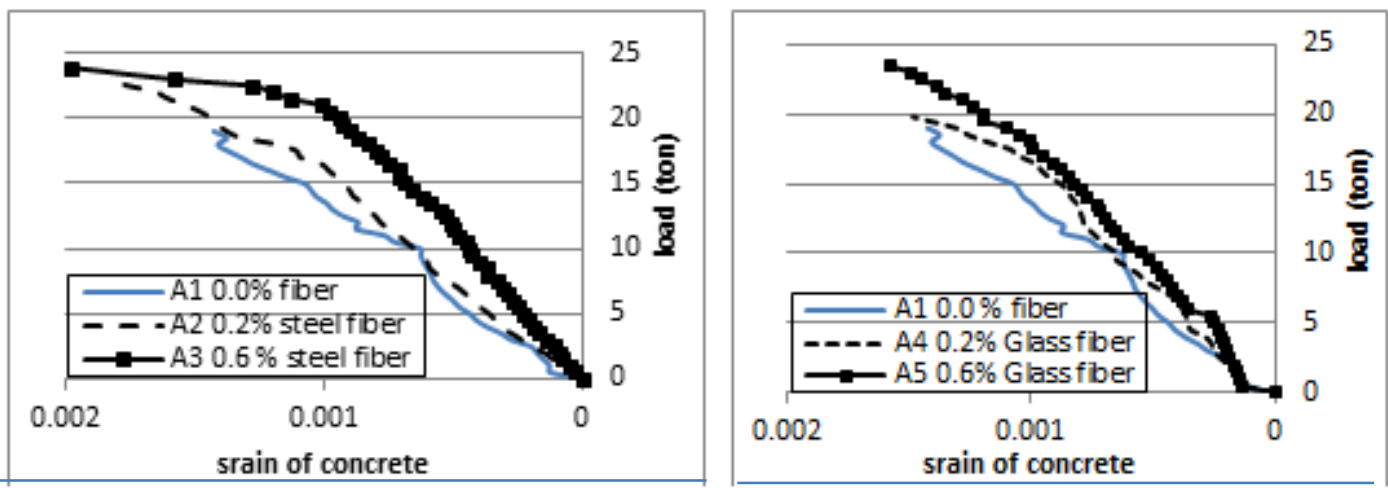

a) First group beams
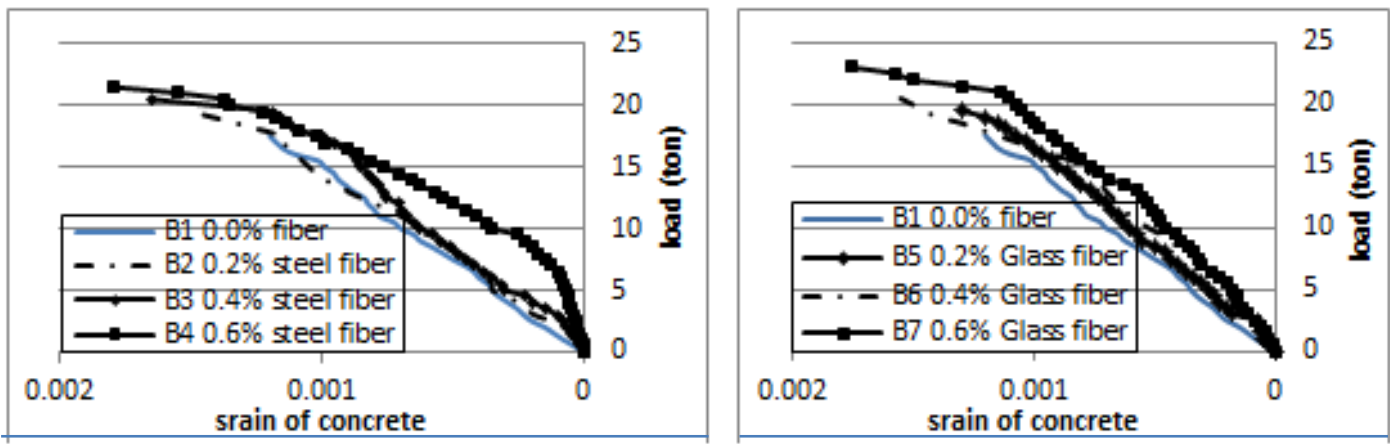

b) Second group beams

Fig. 10. Load-concrete strain curves in compression for beams

\section{Conclusions}

Gist of this research has been presented in this paper with a view to understand the role of fibers on the shear strength of concrete. Based on the study presented in this paper, the study has revealed the following conclusions:

1- The shear cracking load and the ultimate load increase with increasing of the percentage of fibers, because the fibers increase the tensile strength of concrete.

2- The presence of $0.2 \%$ and $0.6 \%$ steel fibers resulted in $12.5 \%$ and $31.25 \%$ increase for the values of the first shear cracking load, respectively. However, they led to $11.43 \%$ and $28.57 \%$ increase for the values of the ultimate load, respectively.

3- The presence of $0.2 \%$ and $0.6 \%$ glass fibers led to the increase of the percentage of the value of the first shear cracking load to $5.88 \%$ and $18.75 \%$, respectively. As well as, led to $2.86 \%$ and $22.86 \%$ increase for the values of the ultimate load, respectively.

4- The addition of fibers not only improved the ultimate load capacity of the tested specimens, but also increased the stiffness and hence reduced the deflection at the same load. This improvement is more pronounced in case of beams reinforced with fibers and stirrups.

5- The values of the maximum deflection increase with the increase of percentage of fibers. This is primarily because concrete becomes more ductile and hence it fails after deformation.

6- The presence of stirrups in the shear zone minimizes the dangerous of the sudden and brittle type of the shear failure. Also, the presence of fiber and stirrups led to increase the value of ductility due to the fact that fibers increase the tensile strength of concrete. 
7- The influence of steel fibers on shear strength, stiffness and ductility of concrete beams is higher than the influence of the glass fiber, because the steel fibers have higher value of the modulus of elasticity and tensile strength.

\section{REFERENCES}

[1] AZIZ, E.M. "Direct Shear strength of fiber reinforced concrete". M.Sc. Thesis, Tikrit University 2000; P.108.

[2] CHOI, K. K.; PARK, H. G.; WIGHT, J. K. "Shear strength of steel fiber-reinforced concrete beams without web reinforcement". ACI Structural Journal, v. 104, n. 1, p.12-21, 2007.

[3] D. J. KIM, M. S. KIM, J. CHOI, H. KIM, A. SCANLON, and Y. H. LEE, "Concrete beams with fiber-reinforced polymer shear reinforcement," ACI Structural Journal, vol. 111, no. 4, pp. 903-911, 2014.

[4] DINH, H. H.; PARRA-MONTESINOS, G. J.; WIGHT, J. K. "Shear behavior of steel fiber-reinforced concrete beams without stirrup reinforcement". ACI Structural Journal, vol. 107, n. 5, p. 597-606, 2010.

[5] HIGASHIYAMA, H., \& BANTHIA, N. "Correlating flexural and shear toughness of lightweight fiber-reinforced concrete". ACI Materials Journal, Vol. 105(3) 251-257, 2008.

[6] KHALOO, A.R., KIM, N. "Influence of concrete and fiber characteristics on behaviour of steel fiber reinforced concrete under direct shear". ACI Materials Journal. Vol.94, No.6, pp. 592-601, 1997.

[7] M. K. DENG, H. Z. SUN, X. W. LIANG, et al., "Experimental study on flexural behavior of high ductile fiber reinforced concrete," Industrial Construction, vol. 20, no. 5, pp. 85-90, 2014 (Chinese).

[8] MAJDZADEH, F., SOLEIMANI, S. M., \& BANTHIA, N. "Shear strength of reinforced concrete beams with a fiber concrete matrix". Canadian Journal of Civil Engineering, Vol. 33(6) 726-734, 2006.

[9] MISAYAH, A. A., \& BANTHIA, N. "Shear strength of steel fiber-reinforced concrete". ACI Materials Journal, Vol. 99(5) 473-479, 2002.

[10] NARAYANAN, R., \& DARWISH, I. Y. S. "Use of steel fibers as shear reinforcement". ACI Structural Journal, Vol. 84(3) 216-227, 1987.

[11] PARRA-MONTESINOS, G. J. "Shear strength of beams with deformed steel fibers". Concrete International, v. 28 n. 11, p. 57-66, 2006.

[12] SHAH, S. P. and RANGAN V. K., "Effect of Glass Fiber Addition on Concrete Strength “, Indian Concrete Journal, Volume 5, Issue 2-6 P". 13-21, 1994.

[13] SLATER, E.; MONI, M.; ALAM, M. S. "Predicting the shear strength of steel fiber reinforced concrete beams". Construction and Building Materials, v. 26, n. 1, p. 423-436, 2012.

[14] SUSETYO, J.; GAUVREAU, P.; VECCHIO, F. J. Effectiveness of steel fiber as minimum shear reinforcement. ACI Structural Journal, v. 108, n. 4, p. 488-496, 2011.

[15] SWAMY, R.N., Jones, R., and CHIAM, T. "Shear transfer in steel fiber reinforced concrete" ACI, SP-105, pp. 565-592, 1989.

[16] Tan, K.H., Mansur, M.A., Shear transfer in reinforced fiber concrete, Journal of Materials in Civil Eng. ASCE, Vol.2, No.4, pp.202-213, 1990.

[17] Y. LI, X. W. LIANG, and M. K. DENG, "Reinforced cement composites under conventional tri-axial compression,” Engineering Mechanics, vol. 29, no. 1, pp. 106-113, 2012 (Chinese).

[18] YAKOUB, H. E. "Shear stress prediction: steel fiber reinforced concrete beams without stirrups.” ACI Structural Journal, v. 108, n. 3, p. 304-314, 2011. 


\section{سلوك القص للكمرات المسلحة بالألياف}

\section{الملخص بالعربي}

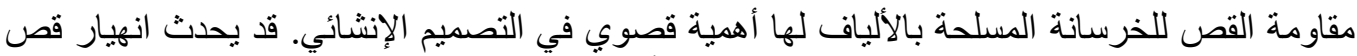

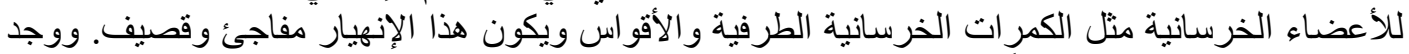

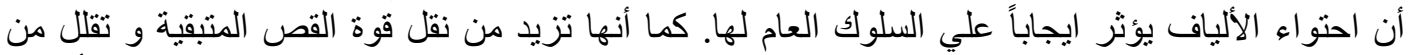

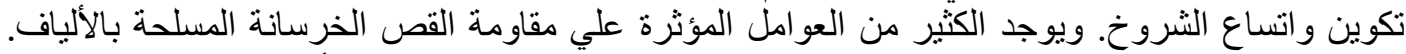

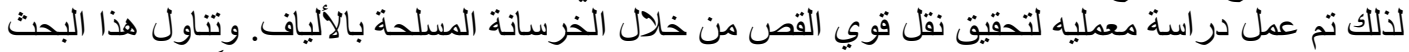

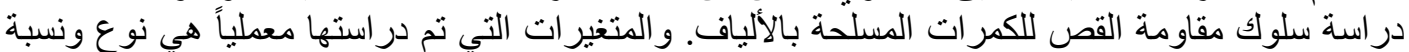

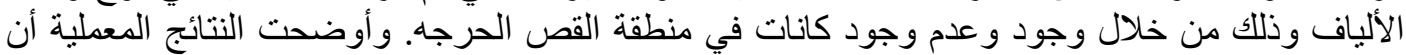

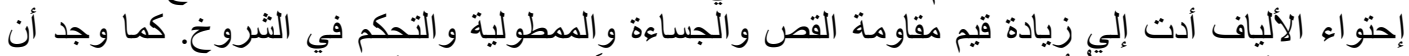

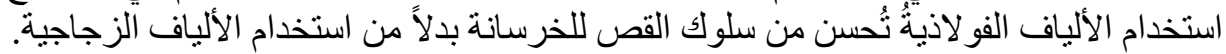

